\title{
Curriculum Design Requirements and Challenges of the Learning Society Approach
}

\author{
Sedighe Karimi ${ }^{1}$, Ahmad-Reza Nasr ${ }^{1} \&$ Mostafa Sharif $^{1}$ \\ ${ }^{1}$ Department of Curriculum Planning, Faculty of Eeducation, University of Isfahan, Isfahan, Iran \\ Correspondence: Sedighe Karimi, Department of Curriculum Planning, Faculty of Education, University of \\ Isfahan, Azadi Square, Isfahan, Iran. Tel: 98-91-3201-1593. E-mail: skarimi929@gmail.com
}

Received: July 19, 2012

Accepted: August 8, 2012

Online Published: October 15, 2012

doi:10.5539/jel.v1n2p143

URL: http://dx.doi.org/10.5539/jel.v1n2p143

\begin{abstract}
Entering the twenty-first century with the development of communities, they are faced with the necessity of moving towards a learning society. University must extend the learning opportunities and improve the quality of them with curriculum design by learning society approach to respond to the necessity. Researchers believe that some conditions for success of this curriculum are required. Present article answers to this question: "Which requirements and challenges university faces with to design a curriculum with learning society approach?" To answer it in a qualitative-quantitative research, the viewpoints of 24 higher education experts through interview and comments of 153 faculty members through a questionnaire were evaluated. The content validity of the questionnaire was confirmed by experts and the reliability was estimated by Cronbach's alpha (0.96). Finally, the results showed that the university faces with these challenges: The non-substitution of learning instead of education; Incomplete identification of the real needs of students and society and non-revision the curriculum to suit the changing needs; Poor communication between levels of higher education curriculum and the previous degrees; Centralization in curriculum planning; Lack of flexibility in curriculum; Inadequate use of curriculum experts and disregarding role of faculty and student to develop the curricula.

Statistical analysis of survey findings also indicated that there is no significant difference among the viewpoints of faculty members about these challenges, based on the variables of gender, education, academic ranking, type of university and experience in teaching and management $(p>0.05)$.
\end{abstract}

Keywords: curriculum requirements, curriculum challenges, learning society

\section{Introduction}

In the late twentieth century, the changes in economy, society and technology appeared all over the world (Morgan et. al, 2007). Considering these circumstances, experts have reminded that nations must convert to learning society to provide the opportunity for the individuals to be lifelong learner which helps them to adapt with the changes (Edwards et al., 2002; Jarvis, 2008). To realize the learning society, university plays an important role (UNESCO, 1997). University should extend the learning opportunities and to improve the quality of them university must develop the curriculum according to the lifelong learning principles The main tool of university in this field is curriculum and the modification in curriculum to make the learning society is a necessity. The condition for success of this curriculum depends on some requirements. Longworth (2004) and Candy et al. (1994) believe that university in compliance with the requirements of the curriculum design with learning society approach faces many obstacles and challenges.

This article tries to answer this question that which requirements and challenges the university faces in curriculum design with learning society approach? To answer this question, the viewpoints of other experts and faculty members in the field of curriculum design requirements with a learning society approach are reviewed. Researchers and advocates of learning society approach to curriculum design believe that the requirements include these six axes:

\subsection{The Substitution of Learning instead of Education}

Today, the demand for traditional education has been decreased. Most of applicants ask for a new orientation in the traditional curriculum and high quality learning opportunities. In response to this demand, the necessity of the curriculum change and method of education based on individualism theories to the theories based on social 
learning should be considered (Jarvis, 2008; Coffild, 2008; Charlton et al., 2005; Chambers, 2010). Social learning theories emphasize that the knowledge and values are obtained in educational institute and society, which makes the individual identity changes and the learning occurs. These theories note the learner's position as a partner in the creation of new knowledge and skills by sharing experiences and knowledge with other students. Therefore university should be a learning society and its curriculum should be designed with the collective culture and an active and participatory approach (Charlton et al., 2005). According to Wenger (1998) university should be a society of practice that acts as a living curriculum for the student. And of course, learning in a society of practice is not limited to novices. The practice of a society is dynamic and involves learning on the part of everyone.

Clearly, the acceptance of such changes in fundamental concepts of education is difficult. Despite the adoption of the social theories of learning, the university education follows still the wrong orientation toward individualism in some countries. Therefore, it has been recommended that the acceptance of a new broad concept of learning needs to apply this theory and requires a broad consensus about philosophy of education in university (Burns, 2011; Day, 1999; Coffild, 2008).

\subsection{Identification of the Real Needs of Students and Society and Revision the Curriculum to Suit the Changing Needs}

Needs assessment is a critical component of the curriculum planning (Fathi Vajargah, 2009). Recognizing the needs, three sources of knowledge, learner and society must be studied. Knowledge is still determining the content in curriculum with the learning society approach. Most of scholars have stated about the learner or society that the focus should be on the interests and needs of learners (Longworth, 2004). According to UNESCO (2005) and Longworth (2004) the idea of learner-centered curriculum also does not mean ignoring the needs of society and there should be an integrated look to society and learner needs. Many researchers believe that university has been inefficient in the field of needs assessment. They have criticized the only emphasis on economic and employment needs of society and non-participation of students in the identification of special needs. As Coffild (2008) and Longworth (2004) recommended, economic objectives of education should be combined with social objectives and founded on a complete collection of the society information. According to Longworth (2004) and Danderea and Gosling (2001), the most important problem regarding the needs assessment is emphasis on speculation of the Curriculum planners and lack of attention to the necessity of scientific needs assessment.

\subsection{Communication between Levels of Higher Education Curriculum and the Previous Degrees}

In the most countries, the educational system includes preschool, elementary, secondary and higher education. They offer a separate form of training and do not form a comprehensive system. This separation leads to the elitism and loss of continuity to maintain the learning interest and motivation (UNESCO, 1997). Advocates of the learning society approach have proposed the replacing of the current system with a lifelong education, which is based on a concept of learning (formal or informal) and the necessity of being lifelong learner (Watterston, 2001). One of the implications of this idea for the educational system is the necessity of close links between the curricula of educational degrees. For this reason, curriculum should be designed to follow the common goal of fostering lifelong learning although the degrees are separate, because the ability and motivation of learning is formed in the primary school and the university just can make it grow (Nasr et al., 2004; Knapper \& Croply, 2000; Watterston, 2001; Tuijnman, 2002; UNESCO, 1997). Such a strong link between curriculum of educational degrees (from preschool to higher education) has not been existed yet.

\subsection{Reduction of Centralization in Curriculum Planning}

The curriculum planning has two major trends in different countries: centralization and decentralization (Norouz-zadeh \& Fathi Vajargah, 2008). The centralized planning system has been the dominant systems yet, but advocates of the learning society approach believe that decentralization is necessary in this system, because the faculty member should be independent to promote the lifelong learning culture and develop the motivation of learning (Smith \& Sporling, 1999). The other reason is that decentralization of the university curriculum planning leads to the competition to maintain the quality of teaching, facilities and other similar factors (Dearing, 1997; World Bank, 2008; UNESCO, 2003). Despite these benefits, decentralization is followed by indifference in the curriculum planning, Lack of the faculty members familiar with the curriculum and inordinate attention to the present conditions and negligence of future (Nasr, et al., 2007). Therefore, the balance between centralized and decentralized strategies must be taken in the curriculum reform. 


\subsection{Flexibility in Curriculum}

Due to the IT development, the self-indirect learning necessity, Heterogeneous student population and Non-traditional students' attendance, standardized and the same curricula should be set aside. The expectation does not match with the requirements of the learning society that a student limits to learn behind a desk, forced with a set of subjects and low choice of them in a limited period of time (Duke, 2002). University should be more flexible and perform the flexibility through the development of distance learning facilities, modular period, development of part-time study and methods for prior learning assessment (Davis, 2003; Schuetz \& Slowey, 2000).

\subsection{The faculty Member and Student Participation in Curriculum Planning Process}

Curriculum is a collective process (Norouz-zadeh \& Fathi Vajargah, 2008). In this process, many individuals and groups are effective. The role and presence of both faculty members and students in the curriculum planning are especially important to advocates of lifelong learning. They believe that faculty members should participate in the curriculum planning because of being familiar with the class and students and the correct identification of their real needs. Faculty members' participation in curriculum planning helps them to perform their role in creating learning culture in the university environment and promotes learning in students' motivation. Some factors prevent the participation of faculty members in the process of curriculum planning such as, lack of practical and professional readiness to participate in curriculum planning, lack of confidence and lack of time (Norouz-zadeh \& Fathi Vajargah, 2008). Another factor in the curriculum planning is student. Capacity, readiness, motivation, effort and students objectives affect on design, implementation and evaluation of the curriculum (Longworth, 2004, Sabar, 1994; Duke, 2002). Majority of faculty members do not trust the learner, while the key point in the Realization of learning society is that the learner as a person, who holds ownership of his learning and can accept the responsibility of his learning should be considered.

\section{Method}

Both qualitative and quantitative approaches were used in different parts of this research. Qualitative methods were used to collect deep and comprehensive data from management and experts. To collect data from faculty members, quantitative method was applied. In addition to answer the research questions, interviews with experts and managers (qualitative part) were used to make the instruments of quantitative part. Totally, this study was designed and implemented as exploratory type of mixed study (Creswell \& Plano Clark, 2007; Hansen et al., 2005).

Statistical society in the qualitative part was consisted of two groups. The first group included managers and assistant managers of universities and government departments working in the cities of Isfahan, Tehran and Shiraz. The second group included experts working in the research institutes that were affiliated to the Ministry of Science, Research and Technology. Selection criteria of managers and experts were teaching and management experience and a background of teaching and research on the issues related to the subject of this study.

To identify the society three ways were used: identification of the authors of Persian books and articles in the subject of this study, identification of known professors who are involved in teaching at universities in the mentioned cities, requesting the interviewees to introduce the people who were experts in the field of research. Finally, 98 persons were appointed as the statistical society.

In quantitative part of research, the statistical society is all faculty members of state universities in the cities of Isfahan, Tehran and Shiraz that were employed in one of these courses of study: Library science, education, sociology, economics, management or computer engineering. Also faculty members that have been working at medical universities in the continuing medical education development center of above-mentioned cities formed another part of this society. Among the faculty, a group was selected as the statistical society. The selection criteria were at least one of the experiences in teaching or research on the subject of this research. To identify this part of the society, two ways were applied. First, visiting the websites of state and medical universities in mentioned cities and review educational and research background of faculty in the named departments. Second, requesting the heads of departments' website for introducing faculty members who have the desired condition and their background were not recorded. Finally 220 people were appointed as the statistical society.

\subsection{Sampling Method and Sample Size}

In the qualitative part of study, intensity sampling method was used to select managers and experts, because the criterion of expertise, experience and knowledge of the study subject were considered for the selection of sample (Gall et al, 2004; Creswell \& Plano Clark, 2007; Cohen et al, 2007; Gray et al, 2007).

In addition, a networked or chain sampling has also been used during the interviews (Gall et al, 2004; Gray, 2004; 
Noy, 2008; Morgan, 2008). In this method, the interviewees were asked to introduce other people who have appropriate study about the research subject.

In qualitative research, the sample size is affected by the intensity sampling strategy (Guest et al., 2006; Noy, 2008; Morgan, 2008; Gall et al., 2004). In the present study, for all known managers and experts as the Statistical Society, an invitation was sent to participate in the interview. Totally, 24 people were ready to participate in the interview.

In quantitative part of research, the simple random sampling was used to select faculty members. About The sample size, using the largest sample is considered as a general rule in quantitative researches. Use of the larger sample increases the probability of being the sample a true representative of society in different variables, and false rejection probability of zero hypothesis (Gall et al., 2004). Since the number of faculty members selected as the society was relatively limited, all of them were selected. Therefore, the conditions of the sample size, independence and equal chance of selection were observed.

\subsection{Measurement Instruments}

Data collection instruments were semi-structured interviews in the qualitative part and questionnaires in the quantitative part as follows:

\subsubsection{Semi-structured Interviews}

This method included asking a series of structured questions and it was followed by the use of more questions to get more information and so the interviewees explained their views in detail (Hancock \& Algozzine, 2006; Gall et al., 2004). By this method of interview, all participants were asked the same questions that were predefined in terms of sequence and structure. However according to the atmosphere conditions of the interview additional questions were posed during conducting the interviews to provide wider information. Also an interview guide was prepared that its questions were designed around the core questions.

\subsubsection{Questionnaire}

Since there was not a standardized questionnaire about the research subject, a questionnaire was made to collect data from faculty members in the form of 8 items (Table 1). To provide this instrument, the results of the interviews were used. Thus after the study and analysis of interviews, principles that must be applied in curriculum planning process with learning society approach were identified, which universities face with challenges in the deployment and compliance of them during the development of learning opportunities.

\subsection{Validity and Reliability of Measurement Instruments and Methods}

In the present study, the following techniques have been used to determine the validity and reliability of methods and instruments.

\subsubsection{Validity and Reliability of the Interview}

As Gall et al. (2004) emphasized, the interview as a measurement instrument, should have the criteria of reliability and validity of other instruments. Therefore, in this study the content validity was used to determine the validity of the interview guide. Moreover, for high accuracy and reliability of data and generalizability of interview results, the method of triangulation was used (Creswell \& Plano Clark, 2007; Gray et al., 2004; Gall et al., 2004). So questionnaires were prepared based on findings of interviews. Text of the interviews were returned to the interviewees to survey by them and were asked to make any modification or change and announce the new comments. In addition, the results of Classification and analysis of the interviews was confirmed by supervisor and consultant. (Gall et al., 2004).

\subsubsection{Validity and Reliability of Questionnaire}

Content validity was used to determine the validity of questionnaires, (Cohen et al, 2007; Sin, 2005). Therefore questions were tried to be content represents which was going to review. To estimate the questionnaires reliability, Cronbach's alpha (0.96) was used.

\subsection{Data Analysis}

Analysis of data obtained from interviews was performed with thematic content analysis (Creswell, 2004; Green, 2004; Gall et al., 2004). According to this method of data collection from interviews, the text of interviews were written and then all the sentences in interviews with the same meaning were put together and a code or name was considered for them in accordance with the embodied concepts in them. After reviewing it, same codes came together and formed the larger categories. Eventually, the interviews were analyzed by the final categorization system. For quantitative data analysis, descriptive and inferential statistics were used by SPSS (17) software. In 
descriptive level, the average, frequency and percentages were calculated. In inferential level, the data were assessed in terms of both normality and Homogeneity of variance, Kolmogorov-Smirnov test for evaluation of scores normal distribution, box test for evaluation of covariance equality hypothesis and Levine test for evaluation of variances equality hypothesis were used. Wherever data had these hypothesis, parametric tests, and otherwise nonparametric tests were used. Conducted tests in this study included one sample t-tests and multivariate analysis of variance and LSD test.

\section{Results}

In this study the findings which includes both quantitative and qualitative, separately have been presented.

\subsection{Analysis of Interviews}

The most important success factor for the realization of a learning society is the curriculum. So far, these institutions have developed their own learning opportunities, but their traditional curriculum has not been reviewed in order to promote quality of opportunity. So, the universities should review their curricula and prepare a curriculum with lifelong learning approach to do their duty in the formation of a learning society. All participants emphasized that the existence of some condition or requirement is necessary to review the curricula. They also emphasized that universities face with some challenges including the following:

3.1.1 Incomplete Identification of the Real Needs of Students and Society and Non-revision the Curriculum to Suit the Changing Needs

Fifteen participants (63\%) announced that information about the real needs of both students and society resources should be identified and designed as infrastructure of curriculum. According to the interviewees, university has always been facing problems in this field. Ten of them (41\%) believe that one of the problems is lack of attention to the needs, interests and expectations of students. The disregard is followed by the consequences such as brain drain and mismatch of graduates' field with their job and reduced motivation and interest in student learning.

Lack of attention to the real needs of society is the other problems of higher education in the process of identifying the needs. Eight of the interviewed (32\%) criticized the university curriculum due to dominate of the occupational and economic needs of society:

The main reason for the incorrect definition of the task is that university has to train manpower for the labor market (P. No. 8).

Interviewees noted the two points:

First, the performance of higher education in response to the needs of labor market has not been successful yet (P. No. 13). The facing of authorities with the needs has not been based on a scientific, planned and Futurism approach (P. No. 17).

The second point, regarding the full set of moral, theological, cultural, artistic and political needs of society is necessary because it is expected that graduates should have the job skills and be active and undertaking citizens.

Interviewees stated that:

University would not look at the needs of students and society in an inclusive and comprehensive way, because there has not been somewhere to be responsible for needs identification in the higher education system and society (P. No. 12).

The other reasons are:

-Lack of cooperation of higher education with other organizations (P. No. 12).

-Non-scientific look at the needs assessment and not using of need assessment patterns (P. No. 3).

Another problem in needs identification is consideration of the needs changes due to the change of social, cultural, economic, scientific conditions and technology. Four of the interviewed (17\%) emphasized, needs assessments should be a persistent process to suit the needs of students and society development, and there is not such a perspective in design and revision of the curriculum. Interviewees considered the two points necessary:

First, it is necessary to get help of learners who are closely associated with developments to identify the new needs.

Second, Carrying out fundamental studies is necessary to identify the developing needs of students and society (P.No.12). 


\subsubsection{Lack of Institutionalization of Policies to Suit the Learning rather than Teaching}

Thirteen participants (55\%) believe that to realize a learning society, in addition to expanding their learning opportunities, Acceptance of a new definition of learning and its implications for university education should be considered to promote quality of learning opportunities. Unfortunately, universities face with the problem in acceptance of this evolution, because the traditional approach in the training process is embedded. According to traditional approach, Education is included the transfer of knowledge from teacher to student and the goal is based on the learning theories of behaviorism and cognitivism (P. No.1). The second reason is that the evolution requires the development of creativity and innovation among the society of university. Although the context is provided with decentralization, But according to six interviewees $(25 \%)$ the spirit of centralization prevents the fundamental efforts of teachers in curriculum planning. In addition, centralization has led to being teachers less familiar with curriculum planning. As a result, Acceptance of new concepts of Education and learning is difficult for them (P. No. 2 and 8). The third reason, according to five interviewees $(20 \%)$, the ambiguity is in the philosophy of higher education and the restriction of university's mission. According to three interviewees (13\%), task of university is limited to train force in Iran (P. No. 18 and 8). This restriction should be set aside. Scholars from different disciplines must think together about the university's mission to reach an agreement. College of human sciences, especially sociology and education departments play a particular role in this case.

\subsubsection{Poor Communication between University Curricula and Previous Degrees}

Eleven interviewees (45\%) stated that if the universities are sought to do their duty towards the formation of learning society, they should look the curriculum of their own and previous degrees on a continuum, because the ultimate goal of the curriculum is lifelong learning.

Essential motivation and competencies to continue learning is formed from the birth in a family, and then the education system should strengthen and develop learner's qualifications (P. No. 20).

There has not been a close relationship between the university and previous degrees about curriculum yet. As a result, many challenges that students face with them are because of the content and teaching methods in the previous degrees (P. No. 13). Interviewees proposed two ways about how to establish this relationship:

- Those involved in higher education curriculum should study curriculum of the previous degrees and offer suggestions, solutions and guidelines for their problems (P. No. 15).

- It is necessary to form a joint committee in structure of the related ministries to study issues and areas of more cooperation in the curriculum scope (P. No. 12).

\subsubsection{Centralization in Curriculum Planning}

Recently, higher education officials have transferred the curriculum planning authority to the universities which have distinguishing staff. Eleven Interviewees (45\%) confirmed the efforts but they believe that universities have not been given enough authority. Being able universities to do their tasks in the forming of learning society, more decentralization of curriculum system is needed. One reason is that fostering creativity, innovation and a sense of responsibility in faculty members, students and other employees is the duty of university, while the product of central planning system is a uniform curriculum that prevents the performance of this task (P.No. 6, 14 and 2). Another reason of decentralization necessity is the need for increasing efficiency of curriculum through participation of all stakeholders, especially student and teacher. Overall, it should be noted that:

Continuing centralization in curriculum planning is a threat, because in consequence university cannot properly perform his duties, and capabilities of academics mostly linger in a vague space, therefore moving towards a learning society will be prevented (P.No. 7).

\subsubsection{Curriculum Inflexibility}

In some countries like Iran, the higher education curriculum is centralized, national and standard which has always been common and uniform. Also university curriculum is developed and is equally implemented in all universities. Ten interviewees (41\%) stated that if the university wants to promote lifelong learning, a sufficiently flexible Curriculum should be prepared. Standard curriculum supports the uniformity of teaching methods rather than its diversity and prevents the creativity and entrepreneurship that results in unemployment of university graduates. Another disadvantage of standard curriculum is the gradual reduction of the faculty members' expertise (P. No. 3). It should be noted that:

Flexibility of national and standard curriculum does not mean that philosophical basics of education and society, and also infrastructure principles and policies of this curriculum must be set aside, but they should be the main indicators (P. No. 3). 


\subsubsection{Insufficient Utilization of Curriculum Professionals to Plan Curriculum}

Eight of those interviewed (33\%) stated that university should scientifically look at curriculum design. Unfortunately, there is no such look because some university faculty is not familiar with the curriculum science. Also there is ambiguity in the knowledge of curriculum (P. No. 7 and 1). Four of the interviewees (17\%) believe that another reason is weaknesses and problems in curriculum and faculty in the curriculum department which caused that they become unable to have effective and highlighted presence in the area of curriculum planning. This group of interviewees including P. No. 14 emphasized that:

Members of curriculum department are seriously responsible for taking action to help other departments.

\subsection{Analysis of Questionnaire Findings}

In this section, views of faculty about their interest rate to requirements of curriculum design with the learning society approach during the development of learning opportunities, and the difference between their views based on demographic factors are examined.

Table 1. Faculty opinion about interest rate to requirements of curriculum design with the learning society approach

\begin{tabular}{|c|c|c|c|c|c|c|c|c|c|c|c|c|}
\hline \multirow{2}{*}{$\begin{array}{l}\text { Requirements of } \\
\text { curriculum design }\end{array}$} & \multicolumn{2}{|c|}{$\begin{array}{l}\text { Very } \\
\text { much }\end{array}$} & \multicolumn{2}{|c|}{ much } & \multicolumn{2}{|c|}{ Partly } & \multicolumn{2}{|c|}{ Little } & \multicolumn{2}{|c|}{ seldom } & \multirow{2}{*}{$\begin{array}{l}\text { No } \\
\text { com. } \\
\text { F }\end{array}$} & \multirow{2}{*}{ Mean } \\
\hline & $\mathbf{F}^{\mathrm{a}}$ & $\mathbf{P}^{\mathrm{b}}$ & $\mathbf{F}$ & $\mathbf{P}$ & $\mathbf{F}$ & $\mathbf{P}$ & $\mathbf{F}$ & $\mathbf{P}$ & $\mathbf{F}$ & $\mathbf{P}$ & & \\
\hline $\begin{array}{l}1 \text { - identify the real needs } \\
\text { of students }\end{array}$ & 1 & 0.7 & 2 & 1.3 & 66 & 43.7 & 54 & 35.8 & 28 & 18.5 & 2 & 2.30 \\
\hline $\begin{array}{l}\text { 2- Identify the real needs } \\
\text { of society }\end{array}$ & 1 & 0.7 & 5 & 3.3 & 45 & 29.8 & 68 & 45 & 32 & 21.2 & 2 & 2.17 \\
\hline $\begin{array}{l}\text { 3- Revision the curriculum } \\
\text { to suit the changing needs }\end{array}$ & 2 & 1.3 & 7 & 4.6 & 63 & 41.7 & 60 & 39.7 & 19 & 12.6 & 2 & 2.12 \\
\hline $\begin{array}{l}\text { 4- Instituting policies to } \\
\text { suit the learning }\end{array}$ & 0 & 0 & 4 & 2.7 & 41 & 27.3 & 66 & 44 & 39 & 26 & 3 & 2.07 \\
\hline $\begin{array}{l}\text { 5-Internal communication } \\
\text { between university } \\
\text { curriculum and previous } \\
\text { degrees }\end{array}$ & 1 & 0.7 & 4 & 2.6 & 52 & 34 & 61 & 39.9 & 35 & 22.9 & 0 & 2.18 \\
\hline $\begin{array}{l}6 \text { - Reduce centralization } \\
\text { in curriculum planning }\end{array}$ & 1 & 0.7 & 8 & 5.3 & 48 & 31.6 & 58 & 38.2 & 37 & 24.3 & 1 & 2.20 \\
\hline 7- flexibility in curriculum & 0 & 0 & 10 & 6.6 & 58 & 38.4 & 61 & 40.4 & 22 & 14.6 & 2 & 2.37 \\
\hline $\begin{array}{l}\text { 8-Get help from experts in } \\
\text { the field of curriculum }\end{array}$ & 1 & 0.7 & 5 & 3.3 & 78 & 51.3 & 39 & 25.7 & 29 & 19.1 & 1 & 2.41 \\
\hline Total Mean & & & & & & & & & & & & 2.23 \\
\hline
\end{tabular}

${ }^{\mathrm{a}}:$ :Frequency

${ }^{\mathrm{b}}$ : Percent (\%)

c: No Comment

Table 1 shows the overall mean (2.23) is less than the hypothesis mean (3). Therefore in terms of faculty, in development of learning opportunities, university has little attention to requirements of curriculum design with the learning society approach. Hence in order to respect these requirements, university faces with the most challenge in instituting learning policies rather than teaching (2.07) and the lowest challenge is in taking advantage of experts in curriculum field (2.41). 
Table 2. Results of one-sample $\mathrm{T}$ test for comparison the views of faculty members with a hypothetical mean of society (3)

\begin{tabular}{llllllr}
\hline Variable & Mean & $\begin{array}{l}\text { Std. } \\
\text { Deviation }\end{array}$ & $\begin{array}{l}\text { Mean } \\
\text { Difference }\end{array}$ & t & df & Sig. \\
\hline Designing curricula & 2.23 & 0.145 & -0.71 & -15.53 & 7 & 0.000 \\
\hline
\end{tabular}

Table 2 shows the calculated $\mathrm{t}(-15.53)$ is more than the critical values and the difference is significant $(\mathrm{p}<0 / 05)$. Accordingly it could be concluded, university faces with the challenges in respect of requirements in curriculum planning with a learning society approach (Table 1).

Table 3. Mean and standard deviation of faculty members' responses in terms of demographic variables

\begin{tabular}{lllll}
\hline Variable & & N & Mean & $\begin{array}{l}\text { Std. } \\
\text { Deviation }\end{array}$ \\
\hline Gender & Female & 47 & 23.7 & 4.9 \\
& Male & 105 & 22.02 & 5.06 \\
Education & MSc & 6 & 24 & 2.8 \\
& PhD Student & 21 & 21.81 & 3.5 \\
Degree & PhD & 126 & 22.69 & 5.2 \\
& Assistant Professor & 82 & 22.01 & 5.03 \\
& Associate Professor & 52 & 22.86 & 4.7 \\
Type of university & Professor & 19 & 24.58 & 4.7 \\
& State University & 113 & 22.28 & 5.0 \\
Experience in & University of Medical Science & 40 & 23.58 & 4.6 \\
teaching and & Less than 10 years & 36 & 21.28 & 3.9 \\
management & 11-20 years & 60 & 22.40 & 4.8 \\
& 21-30 years & 37 & 24.08 & 6.1 \\
& More than 30 years & 20 & 23.00 & 3.9 \\
\hline
\end{tabular}

Table 3 shows, in Compliance with the requirements on curriculum design, mean responses of Women (23.7) is more than men (22.02). Mean response of graduated participants (24) is more than other participants. In terms of academic rank, mean response of faculty with master degrees (24.58) is more than other participants. Mean responses of medical sciences university's faculty (23.58) are more than state university professors (22.28). And in terms of teaching and management experience, mean of participants between 21-30 years experience have the maximum mean (24.08) and those with a experience of less than 10 years, have the minimum mean (21.28).

Table 4. Results of multivariate analysis of variance test on the difference between the views of faculty members based on demographic factors

\begin{tabular}{|c|c|c|c|c|c|c|c|}
\hline Variable & $\begin{array}{l}\text { Sum } \\
\text { Square }\end{array}$ & of $d f$ & $\begin{array}{l}\text { Mean } \\
\text { Square }\end{array}$ & $\mathbf{F}$ & Sig. & $\begin{array}{l}\text { Partial Eta } \\
\text { Squared }\end{array}$ & $\begin{array}{l}\text { Observed } \\
\text { Power }\end{array}$ \\
\hline Gender & 91.971 & 1 & 91.971 & 4.018 & 0.051 & 0.026 & 0.513 \\
\hline Education & 25.846 & 2 & 12.923 & 0.868 & 0.530 & 0.007 & 0.136 \\
\hline Degree & 106.336 & 2 & 53.168 & 2.232 & 0.111 & 0.029 & 0.449 \\
\hline $\begin{array}{l}\text { Type of } \\
\text { university }\end{array}$ & 49.300 & 1 & 49.300 & 2.050 & 0.154 & 0.013 & 0.296 \\
\hline $\begin{array}{l}\text { Experience in } \\
\text { teaching and } \\
\text { management }\end{array}$ & 149.634 & 3 & 49.878 & 2.105 & 0.102 & 0.041 & 0.529 \\
\hline
\end{tabular}


Table 4 shows, there is no significant difference $(p<0 / 05)$ between the views of faculty members based on gender, Degree, academic rank, type of university and teaching and management experience in compliance with requirements of curriculum design with a learning society approach. In other words, universities face with challenges to play their role in the realization of a learning society, in compliance with curriculum design principles.

\section{Discussion}

In the twenty-first century, societies are facing with social, cultural, economic, political changes and increasing development of knowledge and technology. Reviewing these developments, the participants in this study and Morgan et al. (2007), Edwards et al. (2002), Jarvis (2008), UNESCO (1997), Longworth (2004) and Candy et al. (1994) announced that these developments requires conversion of human society to the learning society. In these societies, individuals can continue their learning throughout life and the opportunity is available for them. Obviously, university has an important role in formation of this society. On the one hand, university should expand learning opportunities, and on the other hand, university should ensure their quality through the curriculum in accordance with the principles of lifelong learning. Researchers in other countries found that, there are some essential requirements for success in the curriculum design. These requirements include: the substitution of learning instead of education, Identification of the real needs of students and society and revision the curriculum to suit the changing needs, communication between levels of higher education curriculum and the previous degrees, reduction of centralization in curriculum planning, flexibility in curriculum and the faculty member and student participation in curriculum planning process.

The findings in qualitative study show, experts and managers believe that the most important requirement is identification of the real needs of students and society and revision the curriculum to suit the changing needs. They considered the substitution of learning instead of education as the second priority. But the findings in quantitative study show, faculty members considered the substitution of learning instead of education as first priority and the real needs assessments was in the second place. Regardless of this difference, all of them have emphasized on necessity of compliance with these requirements. Due to the authority transfer of curriculum planning to the university, participants added enough utilization of experts in the field of curriculum to the requirements. The findings of the questionnaires shows (Table 3), the view of faculty becomes more negative with increasing degrees about the requirements of curriculum design compliance with the learning society approach. But the view will tend towards the positive by increasing academic rank and teaching and management experience. Women faculty members have a more positive view than men. Regarding the type of the university, view of faculty members at Medical universities is more positive. Despite these differences in views, all faculty members agree that in compliance with requirements (Table 1) the university faces with challenges (Table 2 and 4 ).

According to the findings of qualitative and quantitative studies, the most important university challenge is lack of the substitution of learning instead of education. The fast growth of science and technology increased demand for high-quality learning opportunities and required the revision of fundamental concepts of the traditional approach which is predominated on university education. Top of for Alpha Education based on individualism learning theory should shift to the concept of learning that is based on social learning theories. According to these theories, learning process is spontaneous and self-directed that occurs through interaction with others and the environment. Implications of this definition for university education includes: emphasis on learning as a shared responsibility, doing learning activities collectively Alpha and conversion of university to a learning organization. Now, some factors prevent institutionalization of policies that are appropriate for new concepts of learning. The factors are such as the domination of the traditional approach to education, lack of faculty preparation for creativity and innovation, lack of their familiarity with the curriculum science, ambiguity and disagreement about manpower training or production of knowledge or a combination of them as the university's mission. Iranian experts, Burns (2011), Day (1999) and Coffild, 2008) have reminded that acceptance of the new concept of learning requires a broad consensus about philosophy of university of education.

Another challenge is incomplete identification of the real needs of students and society and non-revision the curriculum to suit the changing needs. In terms of a learning society, student needs should be the main focus in the process of curriculum planning, because if he is interested and motivated enough to learn, despite all the deficiencies will continue to learn. The other focus is identification of society needs in all aspects of social, cultural, political, moral and economic. Certainly, there should be an integrated look at student and society needs. Unfortunately, Iranian experts, Coffild (2008), Longworth (2004), Danderea and Gosling (2001) believed that in the current curriculum, the student needs have been ignored. Also only the economic needs have been considered about the society's needs, which were not scientific, research-based and futuristic, and have led to the 
phenomenon of graduates' unemployment and have reduced learning motivation.

Another challenge is the poor communication between university curricula and previous degrees. The findings of this study and other researchers such as Nasr et al. (2004), Knapper \& Croply (2001), Watterston (2001), Tuijnman (2002) and UNESCO (1997) show curriculum of the degrees should be considered on a continuum of curriculum that pursues the common goal of fostering lifelong learner. If learning interest and motivation was formed and grown in the previous degrees, the university can play an effective role in strengthening and institutionalizing it. This connection has not been properly yet. Therefore most of students' difficulties and problems return to the content and methods of teaching in previous degrees. Another challenge of university is centralization in the curriculum planning. To accomplish the university mission of forming a learning society, the creativity of professors and students has to grow and they should improve their sense of responsibility to promote curriculum. The requirement is more decentralization that is associated with supervision. Smith \& Sporling (1999) believe that the reason of its necessity is freedom of faculty that is necessary for the development of a learning culture. Dearing, (1997), World Bank (2008) and UNESCO (2003) announced that decentralization is needed to increase the competition for maintaining the quality. However, because of the negative consequences of absolute decentralization, higher education authorities proposed a balance between toatments centralized and decentralized strategies. Another challenge is curriculum inflexibility. This challenge is caused by centralization and focus on the same curriculum in universities. According to the results of this study and findings of Duke (2002), Davis (2003), Schuetze and Slowey (2000), this type of curriculum prevents realization of the learning society. Curricula should be flexible and provide a variety of studies due to the necessity of fostering skills such as self-directed learning and fitting with the adult students conditions. It should be noted that creation of flexibility in standard curriculum does not mean that the principles of national curriculum such as social unity must be ignored but in any case, they should be the main guide. Failure to adequate utilization of the expert's curriculum is the other challenge. In curriculum planning, scientific look and use of knowledge is essential. Unfortunately, the authorities would not take this look. Also many faculty members are not familiar with the curriculum science. Ambiguity and complexity of curriculum science and a minimal consideration of it can also exacerbate this situation. It is more important that faculty and graduates of curriculum planning are not prepared to help other groups in planning of curriculum. In addition, Longworth (2004), Sabar (1994) and Duke (2002) have stated that the faculty and student participation in curriculum planning process should be emphasized. In this research, participants neglect about the teacher and student role in curriculum planning, which is due to the transfer of authority to universities in recent years. About the students, lack of confidence in students and the common notion among the faculty that students do not have enough qualifications prevent them to participate in curriculum planning.

\section{Conclusion}

It could be concluded that the university (in Iran and other countries with similar higher education system) faces with these challenges to planning of curriculum with learning society approach: the non-substitution of learning instead of education, incomplete identification of the real needs of students and society and non-revision the curriculum to suit the changing needs, poor communication between levels of higher education curriculum and the previous degrees, centralization in curriculum planning, lack of flexibility in curriculum, inadequate use of curriculum experts and disregarding role of faculty and student to develop the curricula. And also statistical analysis of survey findings indicated that there is no significant difference among the viewpoints of faculty members about these challenges, based on the variables of gender, education, academic ranking, type of university and experience in teaching and management.

Regarding the above challenges, universities should design learning opportunities to promote a curriculum with the learning society approach. To perform it, the following recommendations seem to be appropriate for all universities with similar higher education system to that of Iran:

- One of the university requirements is the change in definition of its mission, in the education, concept and its elements based on the paradigm of learning. It is necessary to form think tanks in the university, in which scholars from various disciplines reach to consensus about the university's mission. Social sciences and education professionals have an important role in this area. They must define a model of learning society and offer the appropriate behavior template for life in the society. And then, curriculum should be theorized and provide its implementation strategy about the university's role in shaping this society and its method to develop lifelong learners. This task involves carrying out fundamental and applied researches.

- It is necessary to form a committee to take charge of the scientific need assessment in cooperation with various organizations to identify real and comprehensive needs of students and society in the higher education system. 
- Regarding the necessity of the relationship between university curricula with the previous degrees, the university curriculum designers should study previous degrees curriculum and suggest the solution and consult with the system managements. Furthermore, the structure of the ministry should be included a joint council that its task is the study of mentioned areas and development of cooperation in these systems in curriculum field.

- To form the learning society by university two items are essential: decentralization of curriculum planning system and efficiency improvement through the participation of curriculum specialists, faculty and students during the preparation and implementation of programs.

- One of the university obligations to fulfill the learning society is creating flexibility in the curriculum through modular content, combining real and virtual education together and applying the validation of previous learning system in order to match the formal courses more with the students' condition.

- To design the curricula that foster lifelong learners, university requires specialized knowledge of curriculum areas. Hence, it is necessary that curriculum departments take the task serious and overcome their weaknesses through providing the clear and understandable texts for non-specialist in curriculum and developing active participation and cooperation of other departments.

\section{References}

Burns, J. (2011). Capability of United Kingdom Highways Sector. Retrieved from:http://www.rechu/seminar6/doc/tavistoc

Candy, P., Cerbert, G., \& Oleary, J. (1994). Developing lifelong learners, through undergraduate education. Canbera: Astralian Government Publishing Service.

Coffild, F. (2008). Just suppose teaching and learning become the first priority. Retrieved from:http://www.LSNeducation.org.uk

Chambers, J. (2010). The learning society. CICO Systems.Inc.

Charlton, S., Hannan, B., Herrick, C., Landy, M., \& Mahar, S. (2005). Research on learning. Melbourne University: Department of Education and Training.

Cohen, L., Manion, L., \& Marrison, K. (2007). Research methods in education. New York: Routledge.

Creswell, J. (2004). Quantitative inquiry and research design: choosing among five approaches. Thousand Oaks: Sage.

Creswell, J., \& Plano Clark, V. (2007). Designing and conducting mixed methods research. Thousand Oaks: sage.

Danderea, V., \& Gosling, D. (2001). Joining the dots: Reconceptuali educational development. Active Learning in Higher Education, 69(2), 43-55.

Davis, M. (2003). Barriers to reflective practice: The changing nature of higher education. Active Learning in Higher Education, 64(2), 243-255. http://dx.doi.org/10.1177/14697874030043004

Day, Ch. (1999). Developing teachers: The challenges of lifelong learning. London: Flamer Press.

Dearing, R. (1997). Higher education in the learning society. National Committee of Inquiry into Higher Education. Retrieved from http://www.leeds.ac.uk/ educol/niche/

Duke, C. H. (2002). Managing the learning university. USA: SRHE and Open University Press.

Edwards, R., Miller, N., Small, N., \& Tait, A. (2002). Supporting lifelong learning. London and New York: The Open University.

Fathi Vajargah, K. (2009). Principles and concepts of curriculum. Tehran: Ball publication.

Gall, M. D., Borg, W. R., \& Gall, P. J. (1996). Educational research: an introduction (6th ed.). White Plains, NY: Longman.

Gray, D. S., Williamson, J. B., Karp, D. A., \& Dalphin, J. R. (2007). The research imagination: an introduction to qualitative and quantitative methods. Cambridge University Press. http://dx.doi.org/10.1017/CBO9780511819391

Green, J. (2004). Qualitative methods for health research. London: Sage publication.

Guest, G., Bunce, A., \& Johnson, L. (2006). How many interviews are enough? An experiment with data saturation and variability. Field Methods, 18, 59-82. http://dx.doi.org/10.1177/1525822X05279903 
Hancock, D. R., \& Algozzine, B. (2006). Doing case study research: A practical guide for beginning researchers. Colombia university. New York: Teachers College Press.

Hansen, W. E., Creswell, J., Plano Clark, V., Petska, K. S., \& Creswell, J. D. (2005). Mixed methods research designs in counseling psychology. Journal of Counseling Psychology, 52(2), 224-235. http://dx.doi.org/10.1037/0022-0167.52.2.224

Jarvis, P. (2008). Globalization, lifelong learning and the learning society. London and New York: Rotledge.

Knapper, C. H., \& Croply, A. (2000). Lifelong learning in higher education. London: Kogan Page.

Longworth, N. (2004). Lifelong learning in action; Transforming education in the $21^{\text {st }}$ century. London and New York: Routledge Flamer.

Morgan, B., Osborne, K., \& Osborne, M. (2007). The concepts and practices of lifelong learning. London and New York: Routledge.

Morgan, D. (2008). Snowball sampling. In L. Given (Ed.), The sage encyclopedia of anualitative research methods. Thousand Oaks: Sage.

Nasr, A. R., Etemadi-zadeh, H. A., \& Nili, M. R. (2007). Curriculum and Course design. Isfahan: Jahad daneshgahi publication.

Nasr, A. R., Karimi, S., \& Boghratian, K. (2004). The necessity of lifelong learning and the role of university in its realization. Tehran: Institute for Research and Planning in Higher Education.

Norouz-zadeh, R., \& Fathi Vajargah, K. (2008). An Intrroduction to University Curriculum Development. Tehran: Institute for Research and Planning in Higher Education.

Noy, C. (2008). Sampling knowledge: The hermereutics of snowball sampling in qualitative research. International journal of social research methodology, 11(4), 327-344.

Sabar, N. (1994). Curriculum development at school level. The international encyclopedia of education, 126129.

Schuetze, H. G., \& Slowey, M. (2000). Higher education and lifelong learners: International perspectives on change. London and New York: Routledge Flamer.

Sin Leo, Y. M. (2005). Conceptualization and scale development. European journal of marketing, 39(September), 1264-1290.

Smith, J., \& Spurling, A. (1999). Lifelong learning: Riding the tiger. London and New York: Cassell.

Tuijnman, A. (2002). Themes and questions for a research agenda on lifelong learning. Supporting Lifelong Learning, 6-29.

UNESCO World Report. (1997). Learning: the treasure within. Paris: UNESCO publication.

Unesco. (2003). Lifelong learning discourses in Euroup. Homburg: The Unesco institute for education.

UNESCO World Report. (2005).Towards Knowledge Societies. Paris: UNESCO publication.

Watterston, J. (2001). Learning that lasts: Lifelong learning and the knowledge economy. Retrieved from:http://www.icponline.org/featurearticles/f701.htm

Wenger, E. (1998). Communities of practice: learning, meaning, and identity. Cambridge University Press.

World Bank. (2008). Lifelong Learning and Knowledge Society. USA: office of the publisher. 